\title{
Efeito da temperatura e do fotoperíodo na germinação in vitro de esporângios de Peronospora destructor, agente etiológico do míldio da cebola
}

\author{
Leandro Luiz Marcuzzo ${ }^{1}$, Jádina Cristina Vaz Moraes ${ }^{1}$
}

${ }^{1}$ Instituto Federal Catarinense - IFC/Campus Rio do Sul, CP 441, 89.163-356, Rio do Sul, SC

Autor para correspondência: Leandro Luiz Marcuzzo (leandro.marcuzzo@ifc.edu.br)

Data de chegada: 17/06/2017. Aceito para publicação em: 08/08/2017.

$10.1590 / 0100-5405 / 181511$

O míldio da cebola causado por Peronospora destructor (Berk.) Casp. se destaca como a mais importante doença durante o ciclo vegetativo dessa cultura. Essa enfermidade está amplamente disseminada em regiões de clima temperado, onde são frequentes os períodos de temperaturas amenas $\left(\leq 22^{\circ} \mathrm{C}\right)$, alta umidade $(\geq 90 \%)$ e baixa luminosidade. Os primeiros sintomas podem ser observados em qualquer estádio de desenvolvimento da planta, tanto em folhas como em hastes florais aparentemente sadias, através da formação de frutificação acinzentada constituída por esporangióforos e esporângios do patógeno. Com a evolução da doença, ocorre descoloração do tecido afetado, adquirindo tonalidades de verde mais clara do que as regiões sadias das folhas. Ao aumentarem de tamanho, as lesões se alongam no sentido das nervuras e, em seguida, tornam-se necróticas. O conhecimento da biologia do patógeno é de grande importância para compreender a epidemiologia e o desenvolvimento da doença no campo, bem como para tomar medidas de manejo da doença. Diante disto, este trabalho teve como objetivo avaliar em condições in vitro a influência da temperatura e do fotoperíodo na germinação de esporângios de $P$. destructor. A pesquisa foi realizada no Laboratório de Microbiologia e Fitopatologia do Instituto Federal Catarinense/Campus Rio do Sul com esporângios removidos das folhas entre as 6 e 8 horas da manhã (período de liberação do esporângios na planta conforme Sutton \& Hildebrand (5) de folhas verdes de cebola com auxílio de um pincel $\left(n^{\circ} 8\right)$ e lavagem com água esterilizada. A suspensão foi espalhada com uma alça de Drigalski, $100 \mu 1$ de suspensão de esporângios contendo a concentração de $2 \times 10^{5}$ esporângios/mL junto com $100 \mu 1$ de uma suspensão (agitada por 15 minutos) de $10 \%$ de extrato aquoso de fragmentos $(0,5 \mathrm{~cm})$ de folha de cebola (para favorecer a germinação dos esporângios) em placas de Petri contendo meio Agar-Água 1\%. Em seguida, as placas foram incubadas em câmaras de germinação do tipo D.B.O (Demanda Biológica de Oxigênio) a temperaturas de 5, 10, 15, 20, $25,30^{\circ} \mathrm{C}\left( \pm 1^{\circ} \mathrm{C}\right)$ no escuro. Em um segundo momento repetiu-se o experimento incubando os esporângios de P. destructor em D.B.O a $17^{\circ} \mathrm{C}$ (temperatura ideal de germinação obtida com a equação polinomial (Figura 1A)) com os fotoperíodos de 0, 6, 12, 18 e 24 horas luz. Para ambos os experimentos foi avaliada a percentagem de germinação após 72 horas de incubação, já que esporângios de P. destructor têm esse período de tempo para germinarem (1). Para visualização dos esporângios foi adicionado algumas gotas de azul de metileno $0,33 \%$ diluído em água e com movimentos circulares espalhou-se as gotas sobre toda a superfície do meio com o corante. A germinação foi quantificada sob microscópio óptico com a objetiva de 10 vezes, visualizando-se 100 esporângios aleatórios na placa. Foi considerado germinado o que tivesse o tubo germinativo maior que o tamanho do esporângio. Com base nos resultados obtidos, constatou-se a que temperatura exerce grande influência sobre a germinação dos esporângios de $P$. destructor. Observa-se que as maiores percentagens de germinação ocorreram no intervalo de temperaturas entre 15 e $20^{\circ} \mathrm{C}$ (Figura $1 \mathrm{~A}$ ), variando ente 39 e $35 \%$ respectivamente. Hildebrand \& Sutton (3) também observaram em torno de $50 \%$ de germinação na temperatura de $15^{\circ} \mathrm{C}$, valor próximo ao relatado por esses autores. A germinação dos esporângios de $P$. destructor é bruscamente reduzida em temperaturas extremas, como na de $5^{\circ} \mathrm{C}$, onde a percentagem de germinação foi de apenas $2 \%$ e na de $30^{\circ} \mathrm{C}$ não foi observado germinação. Por meio da equação gerada pela curva $\left(y=-0,227 x^{2}+7,835 x-33 ; R^{2}=0,916\right)$ (Figura 1A) a temperatura ótima para a germinação de esporângios de P. destructor foi de $17^{\circ} \mathrm{C}$. Viranyl (6) verificou que a temperatura ótima para a germinação de esporângios de $P$. destructor ocorre entre 10 e $12^{\circ} \mathrm{C}$, valores esses abaixo
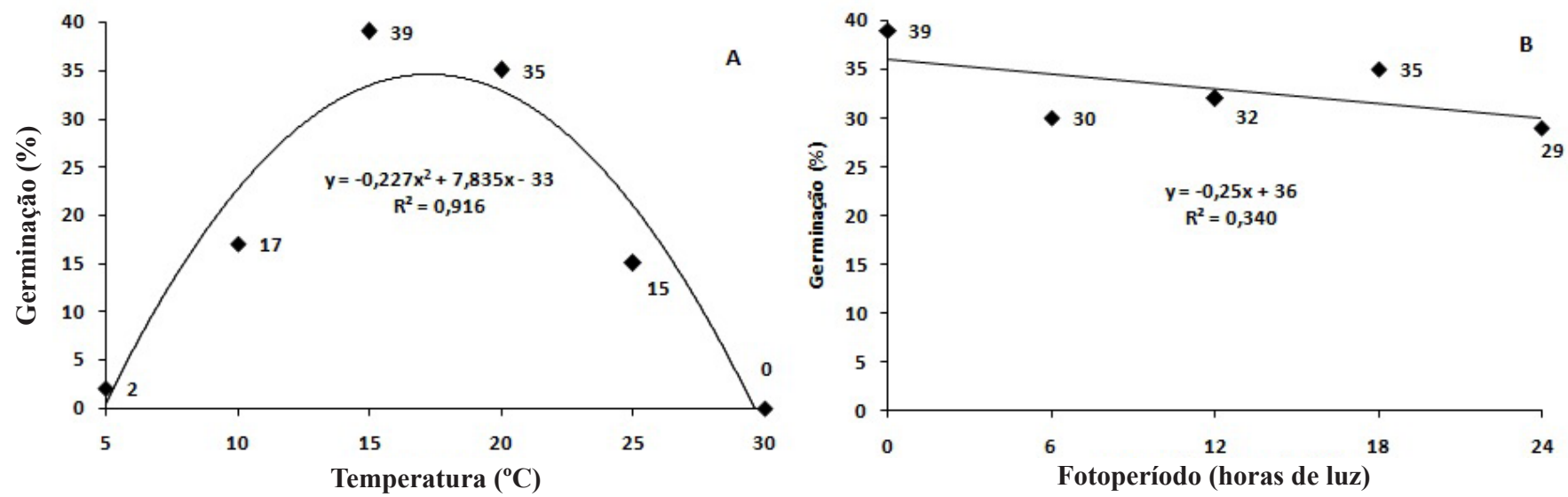

Figura 1. Relação entre a germinação de esporângios de $P$. destructor sob diferentes temperaturas (A) e diferentes fotoperíodos (B). IFC/Campus Rio do Sul, 2017. 
do encontrado no presente estudo. No entanto, Hildebrand \& Sutton (2) verificaram que a formação do apressório após a germinação ocorria na temperatura de 10 a $22^{\circ} \mathrm{C}$, ficando na temperatura média encontrada nesse experimento. Em relação a germinação de esporângios em diferentes fotoperíodos observou-se uma resposta linear (Figura 1B), que através da equação $y=-0,25 x+36\left(R^{2}=0,34\right)$, verificou-se que o fotoperíodo mais favorável ao desenvolvimento é na ausência de luz, com $39 \%$ dos esporângios germinados quando comparado com 24 horas de luz que obteve apenas $29 \%$, porém pouco expressiva a diferença do fotoperíodo ao se comparar com a temperatura. Resultados semelhantes foram obtidos por Marcuzzo \& Eli (4) quando avaliaram a influência do fotoperíodo na germinação de conídios de Botrytis squamosa (Walker), outro patógeno foliar da cebola e constataram que também apresentou o maior percentual de germinação no escuro. Mediante a isso é possível que $P$. destructor tenha sua germinação favorecida por menores períodos de luz, assim em dias nublados e com pouca luminosidade como o que acontece durante o outono/inverno na região do Alto Vale do Itajaí durante o ciclo da cebola favorecem a germinação dos esporângios e a ocorrência da doença. Conclui-se que a germinação dos esporângios foram obtidas em temperaturas de 15 a $20^{\circ} \mathrm{C}$, sendo a temperatura ótima de $17^{\circ} \mathrm{C}$, e no escuro. As informações obtidas em relação à temperatura e o fotoperíodo na germinação dos esporângios de $P$. destructor permitem um maior conhecimento da biologia do agente causal do míldio da cebola, auxiliando assim no entendimento da epidemiologia da doença a campo. Esses resultados servirão de suporte em um sistema de previsão da doença.

\section{REFERÊNCIAS}

1. Abd-elrazik, A.A.; Lorbeer, J.W. A procedure for isolations and maintenance of Peronospora destructor on onion. Phytopathology, St. Paul, v.70, n.8, p.780-782, 1980.

2. Hildebrand, P. D.; Sutton, J. C. Relationships of temperature, moisture, and inoculums density to the infection cycle of Peronospora destructor. Canadian journal plant pathology, Ottawa, v.6, n.2 p.127-134, 1984.

3. Hildebrand, P.D.; Sutton, J.C. Effects of weather variables on spores survival and infection of onion leaves by Peronospora destructor. Canadian journal plant pathology, Ottawa, v.6, p.119-126, 1984.

4. Marcuzzo, L.L.; Eli, K. Effect of temperature and photoperiod on the in vitro germination of conidia of Botrytis squamosa, the causal agent of Botrytis leaf blight of onion. Summa Phytopathologica, Botucatu, v.42, n.3, p.261-263, 2016.

5. Sutton, J. C.; Hildebrand, P. D. Environmental water in relation to Peronospora destructor related pathogens. Canadian journal plant pathology, Ottawa, v.6, p.323-330, 1985.

6. Viranyl, F. Studies on the biology and ecology of onion downy mildew (Peronospora destructor) Berk. (Fries) in Hungary III. Epidemiology of the disease. Acta phytopathologica academiae scientiarum hungaricae, Hungria, v.10, n.3/4, p.321-328, 1975. 